\title{
Removal of a Constraint on the Composition of the Lunar Interior ${ }^{1}$
}

\author{
Don L. Andirrson \\ Seismological Laboratory, Califormia Institute of Technology \\ Pasadena, California 91109
}

\begin{abstract}
Ringwood and Essene (1970) proposed that the $\mathrm{CaO}$ and $\mathrm{Al}_{\infty} \mathrm{O}_{3}$ contents of the deep interior of the moon must be less than $6 \%$ each. This constraint has been generally accepted and has led to models of the lunar interior that are dominated by ferromagnesium silicates. This constraint is invalid. High $\mathrm{CaO}$ and $\mathrm{Al}_{6} \mathrm{O}_{3}$ peridotites have broader intermediate-density (3.3-3.4 $\left.\mathrm{g} / \mathrm{cm}^{2}\right)$ fields than the Ringwood-Essene 'lunar pyroxenite,' and the high-density phase occurs at higher pressure. Likewise, the gabbro-elogite transformation pressure increases with $\mathrm{Al}_{0} \mathrm{O}_{3}$ content. The moon can have a thick plagioclase rich outer shell and a high Ca-Al interior.
\end{abstract}

The values for the moment of inertia and mean density of the moon place important constraints on the composition and mineralogy of the lunar interior. For example, basaltic achondrite meteorites or Apollo 11 basalts cannot be representative of the mean composition of the moon because they transform to dense garnet-bearing assemblages at shallow depth [Wetherill, 1968; O'Hara et al., 1970; Ringwood and Essene, 1970]. Ringwood and Essene [1970] have generalized this situation and conclude that the overall contents of $\mathrm{Al}_{2} \mathrm{O}_{2}$ and $\mathrm{CaO}$ in the moon must be less than 6 and $5 \%$, respectively, and that the moon, like the earth's mantle, is predominantly composed of ironmagnesium silicates. Strictly speaking, their petrologic arguments apply to the source region of the Apollo 11 basalts and not to the moon as a whole. Implicit in their conclusion, although not important for the present discussion, is the assumption that lunar temperatures are subsolidus throughout the moon. This limitation on the calcium and aluminum content has been adopted as a boundary condition by Gast [1972] and Smith et al. [1970] in their discussions of the composition of the lunar interior. Wood et al. [1970] and Wakita and Schmitt [1970] have proposed a chondritic

1 Contribution 2195, Division of Geological and Planetary Sciences, California Institute of Technology, Pasadena, California 91109.

Copyright (c) 1973 by the American Geophyeical Union. interior. The purpose of this note is to point out that the now generally accepted constraint on the $\mathrm{CaO}$ and $\mathrm{Al}_{2} \mathrm{O}_{3}$ content of the lunar interior is not valid. $\mathrm{A}$ high $\mathrm{CaO}$ and $\mathrm{Al}_{2} \mathrm{O}_{3}$ interior can exhibit the desired property of surviving with acceptable densities to $>30 \mathrm{~kb}$ or $>700 \mathrm{~km}$ even at subsolidus temperatures. This removes the main motivation for considering the deep interior of the moon to be ferromagnesium silicates or chondritic in composition.

MacGregor [1970] has studied the effect of $\mathrm{CaO}$ on the stability fields of spinel and garnet peridotites. The situation is clearly summarized by him:

The reaction pyroxene + spinel $\rightleftarrows$ garnet + olivine defines the boundary between low pressure spinel peridotite and high pressure garnet peridotite. Experimental determination in the four component system $\mathrm{MgO}$ $\mathrm{CaO}_{-} \mathrm{Al}_{2} \mathrm{O}_{8}-\mathrm{SiO}_{2}$ indicates that the $\mathrm{CaO}$ content is critical in defining the position of the reaction boundary. Where orthopyroxene is the only pyroxene present, increasing the $\mathrm{CaO}$ content decreases the pressure at which the reaction occurs; where both pyroxenes are present changing the $\mathrm{CaO}$ content has no effect; and where clinopyroxene is the only pyroxene present, increasing the $\mathrm{CaO}$ content increases the pressure of the reaction [MacGregor, 1970, p. 372].

The effect of $\mathrm{CaO}$ in this system is shown on a pressure-composition projection (Figure 1), which is modified from MacGregor [1970]. This is a projection of part of the join, pyropegrossularite, and indicates the pressure at which 


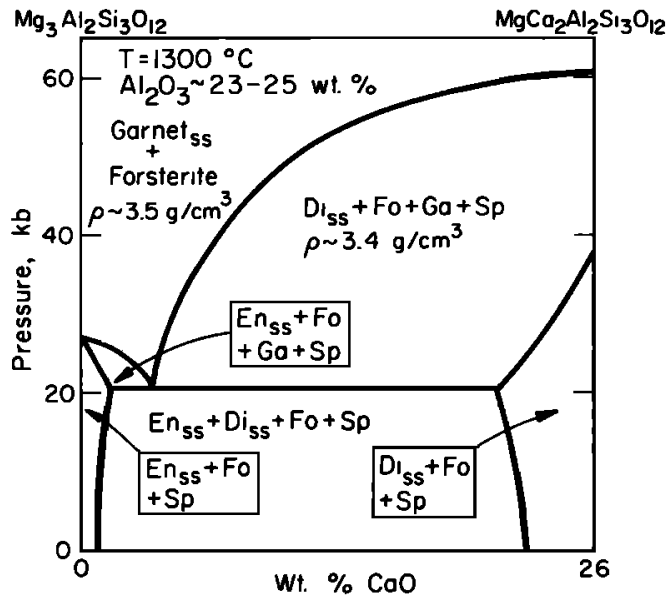

Fig. 1. Pressure-composition projection at $1300^{\circ} \mathrm{C}$ along the join pyrope-grossularite for a simplified peridotite [MacGregor, 1970].

the reactions occur as a function of $\mathrm{CaO}$ content. The $\mathrm{Al}_{9} \mathrm{O}$, content is relatively constant throughout the figure at 23-25 wt \%. With increasing pressure, compositions involving two pyroxenes are the first to react to the highpressure assemblage, and changes in the $\mathrm{CaO}$ content will not change the reaction pressure.

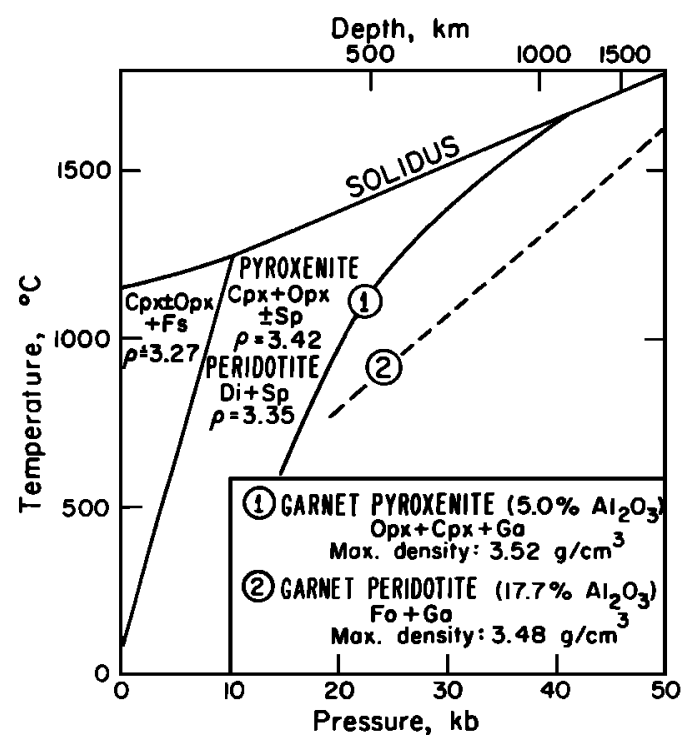

Fig. 2. Stability fields and densities of mineral assemblages displayed by $\mathrm{Ca}-\mathrm{Al}$ deficient model lunar pyroxenite [Ringwood and Essene, 1970] and $\mathrm{Ca}-\mathrm{Al}$ rich peridotite, $19.5 \% \mathrm{CaO}$, $17.7 \% \mathrm{Al}^{\circ} \mathrm{O}$. [MacGregor, 1970].
For very $\mathrm{CaO}$ poor, or $\mathrm{CaO}$ rich, compositions the transformation pressure depends on the $\mathrm{CaO}$ content. In the $\mathrm{CaO}$ poor field, increasing the $\mathrm{CaO}$ content decreases the pressure of reaction. In the $\mathrm{CaO}$ rich field, increasing the $\mathrm{CaO}$ content increases the pressure of reaction. The completion of the reaction to the dense' assemblage initially decreases with $\mathrm{CaO}$ content, and then $\mathrm{CaO}>3 \frac{1}{2}$ wt \% (in this projection) increases. The transformation pressures for spinel to garnet pyroxenite or peridotite for a natural peridotite [Ito and Kennedy, 1967], 'pyrolite III' [Green and Ringwood, 1967b], and a 'model lunar pyroxenite' [Ringwood and Essene, 1970] agree well with this figure, even though their $\mathrm{Al}_{9} \mathrm{O}_{3}$ contents are only 2-5 wt \%. The lunar moment of inertia data suggests that the density distribution is almost uniform. Clearly, this is more nearly the case for a $\mathrm{CaO}$ rich than for a $\mathrm{CaO}$ poor moon. A more general description of the phase relationships in the four-component system $\mathrm{CaO}-\mathrm{MgO}-\mathrm{Al}_{2} \mathrm{O}_{3}-\mathrm{SiO}_{2}$ is given by MacGregor [1968].

Figure 2 shows the stability fields of the Ringwood-Essene 'model lunar pyroxenite' and, for comparison, the equilibrium boundary be-

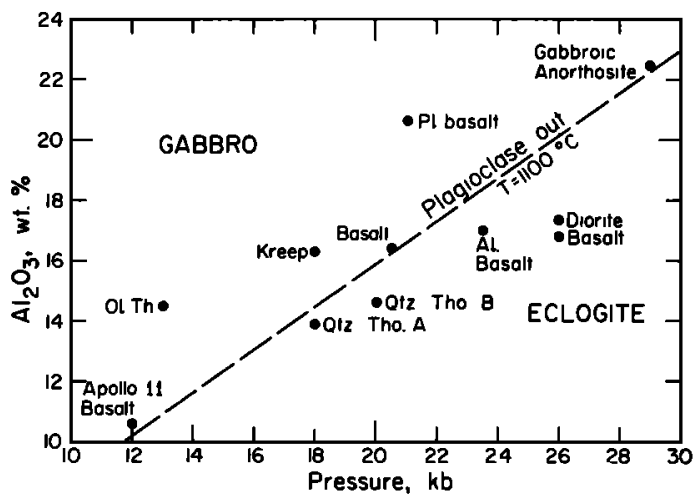

Fig. 3. The gabbro-eclogite reaction boundary as a function of $\mathrm{Al}_{s} \mathrm{O}$, content. Data were taken from the following sources: basalts, Ito and Kennedy [1970] and Cohen et al. [1967]; aluminous basalt, Green [1967]; quartz and olivine tholeiite, Green and Ringwood [1907a]; diorite and gabbroic anorthosite, Green [1970]; Apollo 11 basalt, Ringwood and Essene [1970]; KREEP and plagioclase basalt, Ringwood and Green [1972]. The materials on the high-pressure side of the dashed line mostly have more $\mathrm{SiO}_{\text {a }}$ and less $\mathrm{CaO}$ than those on the low-pressure side. The $\mathrm{CaO}$ contents range from 7 to 13 wt $\%$. 
tween a spinel peridotite and garnet peridotite [MacGregor, 1970]. The latter contains 17.7-wt $\% \mathrm{Al}_{2} \mathrm{O}_{3}$ and 19.5-wt \% $\mathrm{CaO}$. Note that the spinel peridotite field is much broader than the 'lunar' pyroxenite field, and the densities in both the spinel-bearing and garnet-bearing fields are lower than those in the comparable 'lunar' pyroxenite fields. The high-pressure field, for the $\mathrm{CaO}$ and $\mathrm{Al}_{2} \mathrm{O}_{3}$ rich assemblage, can be avoided entirely in the moon even at subsolidus temperatures.

The effect of $\mathrm{Al}_{2} \mathrm{O}_{3}$ content on the basalt $\rightarrow$ eclogite reaction also deserves some comment. Figure 3 shows the 'plagioclase out' boundary as a function of $\mathrm{Al}_{2} \mathrm{O}_{3}$ content at $1100^{\circ} \mathrm{C}$. Although the $\mathrm{Al}_{2} \mathrm{O}_{8}$ content is not the only factor controlling the reaction pressure, there is a clear tendency for the basalt-eclogite boundary to increase in pressure as the $\mathrm{Al}_{2} \mathrm{O}_{3}$ content increases. The $\mathrm{Na}$ and $\mathrm{Fe}$ contents also affect the location of the boundary. Plagioclase, and therefore gabbro, is stable in a highly aluminous crust to great depth. A similar point has been made by Ito and Kennedy [1971]. Gast [1972] and Anderson [1973] have both suggested a $\mathrm{Ca}$ and Al rich outer shell of great [150-250 km] thickness.

Figure 4 gives the stability fields in three $\mathrm{Ca}$ and $\mathrm{Al}$ rich systems and, for comparison, a lunar temperature curve. Although none of these materials necessarily represent the composition of the deep interior, Figure 4 again makes the point that the $\mathrm{CaO}$ and $\mathrm{Al}_{2} \mathrm{O}_{3}$ contents of both the crust and the mantle cannot be required to be small. The intermediatedensity field $\left(\rho=3.3-3.4 \mathrm{~g} / \mathrm{cm}^{3}\right)$ in these two high $\mathrm{Ca}-\mathrm{Al}$ systems extends to greater depth than the 'model lunar pyroxenite' intermediatedensity $\left(\rho=3.42 \mathrm{~g} / \mathrm{cm}^{3}\right)$ field.

The gabbroic anorthosite is similar in composition to that inferred to be appropriate by Gast [1972] and Anderson [1973] for the

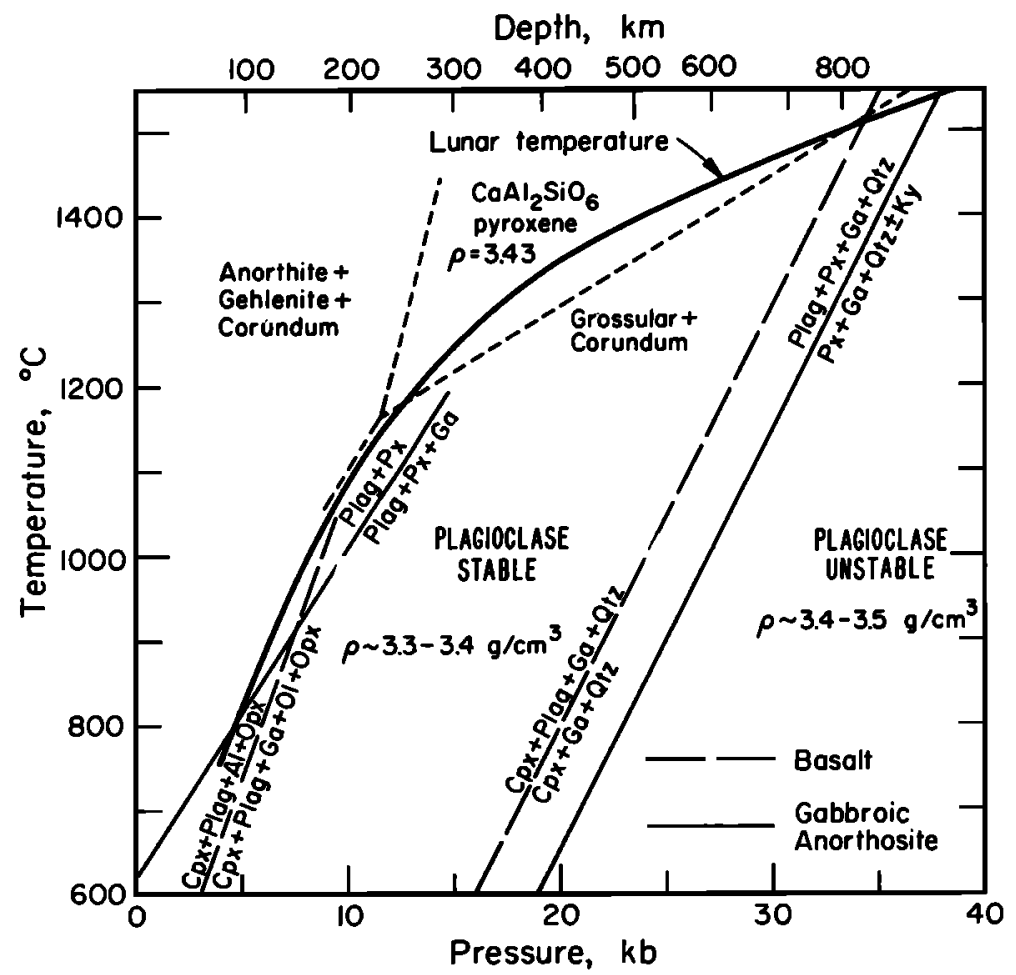

Fig. 4. Stability fields of three $\mathrm{Ca}-\mathrm{Al}$ rich assemblages from Ito and Kennedy [1970] (basalt), Green [1970] (gabbroic anorthosite), and Hayes [1966] (Ca AlsiOa), in relation to a lunar temperature profile from Hanks and Anderson [1972]. Ito and Kennedy [1970, 1971] also suggest a very broad intermediate-density field in Ca-Al rich assemblage. 
outer shell of the moon. For the lunar temperature profile shown, the low-pressure assemblage is stable between 80 and $370 \mathrm{~km}$.

It has been proposed [Anderson, 1973] that the moon represents a high-temperature condensate from the solar nebula. In particular, it was proposed that the moon is enriched in the pre-iron condensates, which include $\mathrm{Ca}$, $\mathrm{Al}$, and $\mathrm{Ti}$ compounds and the refractory trace elements such as $\mathrm{Ba}, \mathrm{Sr}, \mathrm{U}, \mathrm{Th}$, and the REE. The residual crystals in this assemblage at lunar pressures are spinel, perovskite, and merwinite. The exterior shell, or crust, in this model is $250 \mathrm{~km}$ thick and is composed mainly of pyroxene and anorthite. It is enriched in Fe and the volatiles relative to the interior. Trace element distribution patterns suggest that the average composition of the crust is $\sim 80 \%$ anorthosite and $\sim 20 \%$ mare-type basalts. A thin garnet rich layer with high density and high seismic velocity can be stable in the crust (see Figure 4), depending on the temperature and composition.

Acknowledgments. I would like to acknowledge the helpful suggestions of P. Gast, A. E. Ringwood, G. Kennedy, and I. MacGregor.

This research was supported by the National Aeronautics and Space Administration under contract NASA NGL 05-005-0069.

\section{References}

Anderson, D. L., The composition and origin of the moon, Earth Planet. Sci. Lett., in press, 1973.

Cohen, L. H., K. Ito, and G. C. Kennedy, Melting and phase relations in an anhydrous basalt to 40 kilobars, Amer. J. Sci., 265, 475-518, 1967.

Gast, P. W., The chemical composition and structure of the moon, The Moon, 5, 121-148, 1972.

Green, T. H., An experimental investigation of sub-solidus assemblages formed at high pressure in high-alumina basalt, kyanite eclogite and grosspydite compositions, Contrib. Mineral. Petrol., 16, 84-114, 1967.

Green, T. H., High pressure experimental studies on the mineralogical constitution of the lower crust, Phys. Earth Planet. Interiors, \&, 441-451, 1970.

Green, D. H., and A. E. Ringwood, An experimental investigation of the gabbro to eclogite transformation and its petrological applications, Geochim. Cosmochim. Acta, 31, 767-833, 1967a.
Green, D. H., and A. E. Ringwood, The stability fields of aluminous pyroxene peridotite and garnet peridotite and their relevance in upper mantle structure, Earth Planet. Sci. Lett., \&, 151-160, 1967b.

Hanks, T., and D. L. Anderson, Origin, evolution and present thermal state of the moon, Phys. Earth Planet. Interiors, 5, 409-425, 1972.

Hayes, J. F., Lime-alumina-silica, Carnegie Inst. Washington Year Book, 65, 234-239, 1966.

Ito, K., and G. C. Kennedy, The fine structure of the basalt-eclogite transformation, Min. Soc. Amer. Spec. Pap. 3, 77-83, 1970.

Ito, K., and G. Kennedy, An experimental study of the basalt-garnet granulite-eclogite transition, in The Structure and Physical Properties of the Earth's Crust, Geophys. Monogr. Ser., vol. 14, edited by J. Heacock, p. 261, 1971.

MacGregor, I. D., Depth of origin of basaltic magmas, J. Geophys. Res., 79, 3737, 1968.

MacGregor, I. D., The effect of $\mathrm{CaO}_{2} \mathrm{Cr}_{2} \mathrm{O}$, $\mathrm{Fe}_{2} \mathrm{O}_{3}$ and $\mathrm{Al}_{2} \mathrm{O}_{3}$ on the stability of spinel and garnet peridotites, Phys. Earth Planet. Interi ors, 3, 372-377, 1970.

McConnell, R. K., and P. W. Gast, Lunar thermed history revisited, The Moon, 5, 41-51, 1972.

O'Hara, M. J., G. M. Biggar, S. W. Richardson, C. E. Ford, and B. G. Jamieson, The nature of the seas, mascons and the lunar interior in the light of experimental studies, Geochim. Cosmochim. Acta, 94, Suppl. 1, 695-710, 1970.

Ringwood, A. E., and E. Essene, Petrogenesis of Apollo 11 basalts, Internal constitution and origin of the moon, Geochim. Cosmochim. Acta, 34, Suppl. 1, 769-799, 1970.

Ringwood, A. E., and D. H. Green, Petrogenesis of Lunar Highland basalts; Internal constitution and origin of the moon, Geochim. Cosmochim. Acta, 86, Suppl. s, 573-575, 1972.

Smith, J. V., A. T. Anderson, R. C. Newton, E. J. Olsen, and P. J. Wyllie, A petrologic model for the moon based on petrogenesis, experimental petrology and physical properties, J. Geol., 78, 381-405, 1970.

Wakita, H., and R. Schmitt, Lunar anorthosites: Rare-earth and other elemental abundances, Science, 170, 969-974, 1970.

Wetherill, G. W., Lunar interior: Constraint on basaltic composition, Science, 160, 1256-1257, 1968.

Wood, J. A., J. S. Dickey, Jr., J. B. Marvin, and B. N. Powell, Lunar anorthosites and a geophysical model of the moon, Geochim. Cosmochim. Acta, 34, Suppl. 1, 965-988, 1970.

(Received August 3, 1972; revised December 19, 1972.) 